\title{
Bird Flu, the OIE, and National Regulation: The WTO's India-Agricultural Products Dispute
}

\author{
CHAD P. BOWN* \\ The World Bank and CEPR \\ JENNIFER A. HILLMAN** \\ Georgetown University Law Center
}

\begin{abstract}
This paper provides a legal-economic assessment of issues arising in the Panel Report over the WTO's India-Agricultural Products dispute, one of a growing list of disputes arising at the intersection of the WTO and domestic regulatory policy over human, animal, or plant health. This dispute featured allegations that India's import measures applied against avian influenza- (AI-) infected countries over poultry and related products were too restrictive, in light of the World Organisation for Animal Health's (OIE's) scientifically motivated standards and guidelines. We rely on insights from a set of economic models of commercial poultry markets in the presence of negative externalities such as AI. We use such models to motivate critical tradeoffs arising at the intersection of government regulatory regimes designed to deal with AI and how they fit alongside trade agreements such as the WTO and standard-setting bodies such as the OIE, which combine to impose constraints on regulatory and trade policy. While we find the institutional design of the OIE to be well-motivated and we are in broad agreement with the overall thrust of the Panel Report in the dispute, we also highlight a number of subtle issues which pose longterm challenges for the multilateral trading system's ability to balance trade rules with public health concerns.
\end{abstract}

\section{Introduction}

The WTO's India-Agricultural Products dispute ${ }^{1}$ involves a US challenge to the Indian government's regulatory policies for addressing avian influenza (AI) - otherwise known as 'bird flu'. While India had not been a major market for

\footnotetext{
*Email: cbown@worldbank.org.

**Email: jah95@law.georgetown.edu.

Thanks to Kyle Bagwell, Robert Staiger, Nuno Limão, Arik Levinson, Ellen Terpstra, Clem Clay and seminar participants at the WTO Case Law conference at European University Institute and the Peterson Institute for helpful discussions. Semira Ahdiyyih provided outstanding research assistance. Bown acknowledges research funding through the World Bank's MDTF-II Trust Fund. Any opinions expressed in this paper are the authors' own and should not be attributed to the World Bank. All remaining errors are our own.

1 Panel Report, India - Measures Concerning the Importation of Certain Agricultural Products, WT/DS430/R. The Panel Report was modified by the Appellate Body after the writing of this article and
} 
US poultry exports, the decision by India to ban imports of poultry meat, eggs, feathers, and seven other products from any country that reported an AI outbreak in its territory raises a number of important legal, economic, and public policy issues.

Our analysis of the dispute explores the relationship between WTO Members, the WTO Agreements, and international standards setting organizations, including the World Organisation for Animal Health (OIE). ${ }^{2}$ The dispute calls into question the appropriate design for international institutions that establish health and safety standards, how such institutions interact with domestic regulators, and the indirect constraints that such institutions place on domestic policymaking via membership in the WTO.

While this dispute also joins a growing list at the intersection of the WTO and domestic regulatory policy over human, animal or plant health, ${ }^{3}$ its central concerns are also of both immediate and long-term policy relevance. Given continued outbreaks of AI globally - including major new outbreaks in the United States in 2014-15 - our assessment of the Panel Report and the OIE underscores the need to find the appropriate balance between a country's right to regulate for the health and safety of its people, animals, and plants, while at the same time participating in a rules-based trading system that relies on science-based assessments of the risks of continuing to trade in products from countries found to harbor infectious diseases or contagious viruses.

\section{Economic and policy background}

\subsection{Avian influenza and the OIE}

Avian Influenza is an infectious viral disease that arises in birds, and, in particular, wild water fowl such as ducks and geese. While AI is mainly carried in wild birds, it can be transmitted to domestic poultry. Scientists have developed criterion by which to classify the many different (and mutating) strains of the AI virus so that they fall into one of two categories: high pathogenic notifiable avian influenza (HPNAI) and low pathogenic notifiable avian influenza (LPNAI). ${ }^{4}$

was adopted, as modified by the Appellate Body Report on 19 June 2015. Throughout this paper, the Panel Report will be referred to as India-Agricultural Products, WT/DS430/R.

2 The World Organisation for Animal Health, formerly known as the International Office of Epizootics (OIE), is the international organization responsible for establishing health standards for international trade in animals and animal products, including standards relating to avian influenza.

3 Other legal-economic assessments of related disputes in this series include Horn and Weiler (2003) EC-Asbestos; Neven and Weiler (2006) Japan-Apples; Howse and Horn (2009) EC-Approval and Marketing of Biotech Products; Bown and Trachtman (2009) Brazil-Retreaded Tyres; and Hoekman and Trachtman (2010) EC-Hormones. This case is the 38th dispute raising claims under the WTO's Agreement on the Application of Sanitary and Phytosanitary Measures.

4 In the scientific literature, these are more frequently referred to as HPAI and LPAI. We adapt the HPNAI/LPNAI terminology to remain consistent with OIE guidelines described below on what is 'notifiable' to the global community. 
Thus far, the evidence linking most forms of AI to humans is weak, though certain strains of AI have resulted in human infections-including H5N1 and H7N9 - these strains hold the potential to cause a global public health crisis. The transmission of the virus to humans is thought to have occurred based on direct or indirect contact with live or dead infected poultry. ${ }^{5}$ There is no evidence thus far that the virus can be transmitted through poultry meat that has been cooked according to established guidelines.

The OIE is the international organization that establishes the 'standards' defining what it means for poultry to potentially be infected with AI and thus for one country to be able to implement trade barriers on poultry-related products arising from AI-infected trading partners. The OIE does this through a process by which it develops and maintains Scientific Commissions composed of outside subject experts, and it then publishes (and updates) the recommendations of such experts as standards via a legal document referred to as its Terrestrial Code.

Chapter 10.4 of the OIE's Terrestrial Code provides detail on the latest standards relating to the detection of Avian Influenza and commercial poultry products, such as live birds, eggs and feathers. In particular, paragraph 1 of Chapter 10.4.1 of the Terrestrial Code clearly delineates the distinction between HPNAI and LPNAI by establishing a definition for when a particular mutation of an AI virus is sufficiently deadly to be classified as HPNAI; any forms of AI that do not meet that threshold are then classified as LPNAI.

The Terrestrial Code develops additional policy guidelines for countries in the face of their own and their trading partners' AI status - i.e., whether countries or sub-regions (zones) within a country are 'NAI-free' (no evidence of HPNAI or LPNAI) or at least 'HPNAI-free' (while evidence of LPNAI may exist, no evidence of HPNAI exists). This includes discussion of surveillance regimes, stamping out procedures in light of NAI infections and outbreaks, and defining the length of incubation periods (e.g., 21 days). There are also different procedures for different types of products; e.g., live birds other than poultry, eggs (for hatching or human consumption), feathers, and other poultry products. Importantly, the Code explains how a country can regain NAI-free status after an NAI outbreak, and the extremely sharp distinctions between HPNAI versus LPNAI infections. The Code makes explicit the conditions under which trading partners are (and are not) justified in imposing import bans in light of NAI outbreaks, and it has an established procedure permitting importing countries the right to 'escape'

5 According to the FAO (2014), H5N1 is an HPNAI virus first discovered in 1996 in Guangdong province, China in a goose on a goose farm. The first of 18 cases of human infection arose in Hong Kong in 1997, resulting in six deaths. A massive culling of poultry in the region was instituted so as to stamp out the epidemic. The H5N1 HPNAI virus re-emerged in humans on a larger scale in February 2003 in Hong Kong and later in Korea, Thailand, and Vietnam. In early 2013, a new LPNAI strain emerged in China, where $\mathrm{A}(\mathrm{H} 7 \mathrm{~N} 9)$ was found to have infected more than 470 humans resulting in more than 170 deaths. Other mutations of LPNAI strains have also subsequently emerged in other areas of Asia, including Korea and Japan and other areas of China, resulting in human deaths. 
from obligations and deviate from OIE standards, so long as they provide their own risk assessment and scientific evidence.

\subsection{The policies under dispute}

Table 1 provides a timeline of the Indian policies related to Avian Influenza and poultry that form the crux of the WTO dispute.

On 5 July 2001, the Indian government amended the 1898 Livestock Act with the Live-Stock Importation (Amendment) Act of 2001. The US interest in the extent to which the Livestock Amendment Act applied to poultry products in light of avian influenza dates at least to 2007 according to minutes from the WTO SPS Committee meetings held that summer. The Government of India's Department of Animal Husbandry, Dairying, and Fisheries (DAHD) issued S.O. 1663(E) on 19 July 2011, an order imposing an import ban (and other traderestricting measures) on a number of poultry-related products from countries reporting NAI, including both HPNAI and (importantly) LPNAI. On 7 October 2011, India notified S.O. 1663(E) to the WTO's SPS Committee, and on 6 March 2012, the US requested consultations with India under the WTO.

\subsection{Economic markets for poultry and related products}

The commerce at issue in this dispute consisted of a number of poultry and livestock-related products that could potentially be affected by avian influenza. ${ }^{6}$ To analyze the potential impact of the policies under dispute, we focus below mainly on poultry, the most economically vibrant of these product markets globally and representative of a number of the salient political-economy issues in the dispute.

The United States is the world's largest producer of poultry and home to household brands such as Tyson Foods and Perdue. These and other large agribusinesses have historically been able to organize politically so as to overcome the free-rider problem and engage with the office of the US Trade Representative to work on their behalf on market-opening issues related to trade policy. Indeed, commercial poultry is no stranger to trade disputes. Between 1995 and 2014, at least seven antidumping investigations over poultry were initiated globally involving ten different countries (Bown, 2015), and no fewer than 12 formal WTO disputes over poultry were initiated under the DSU involving nine different WTO members.

6 The US' request for the establishment of a panel listed domestic and wild birds (including poultry and captive birds), day old chicks, ducks, turkey, and other newly hatched avian species; un-processed meat and meat products from Avian species, including domesticated, wild birds and poultry; hatching eggs; eggs and egg products, un-processed feathers, live pigs, pathological material and biological products from birds, products of animal origin (from birds) intended for use in animal feeding or for agricultural or industrial use; and semen of domestic and wild birds including poultry (India-Agricultural Products, WT/DS430/R). 
12 August 1898 Indian Livestock Importation Act, 1898 (9 of 1898) (Livestock Act).

5 July $2001 \quad$ Livestock Act amended by the Live-Stock Importation (Amendment) Act 2001 (No. 28 of 2001) comes into force, though not published in the Official Gazette of India until August 29, 2001.

27-28 June 2007 For the first time, US raises concerns at WTO SPS Committee meeting that India was banning poultry, swine, and other products based on detection of LPNAI in wild birds in some parts of the US; the US claimed restrictions far exceeded OIE standards and did not recognize regions in the US with no LPNAI or others with no HPNAI, and applied the ban to products that had been treated or processed sufficiently to kill the AI virus.

October 2007- $\quad$ At most WTO SPS Committee meetings, the US (and sometimes the EU and others) 2010 continued to raise concerns about India's AI-related import bans, consistently complaining that the bans went beyond OIE guidelines and were not based on scientific evidence.

October $2010 \quad$ At the WTO SPS Committee meeting, India provides to the US and EU a document titled 'India's Risk Assessment on Avian Influenza for imposing ban on import of poultry and poultry products from Avian Influenza positive countries'.

20 June-1 July The EU, the US, and Australia complained at the SPS Committee meeting that India's 2011 risk assessment was incomplete and insufficient. India noted that the document was provided to the US and the EU at their request and was not India's final risk assessment.

19 July 2011 Government of India's Department of Animal Husbandry, Dairying, and Fisheries (DAHD) issues S.O. 1663(E) in exercise of powers conferred by the Livestock Act, coming into effect the same date.

7 October $2011 \quad$ S.O. 1663(E) notified to the WTO's SPS Committee.

6 March $2012 \quad$ US requests consultations with India under the WTO.

Source: Compiled by the authors from Panel Report and minutes of the SPS Committee.

The US is the second largest exporter of poultry meat behind Brazil (USDA, 2015a); between 2005 and 2010, for example, the US exported an average of $15 \%$ to $20 \%$ of its total domestic broiler production each year. By 2012, US export sales to the world were over $\$ 5$ billion, and the largest US export markets for poultry were Mexico, Canada, China, Hong Kong, Taiwan, Angola and Kazakhstan.

Despite the potential market access interests for the highly populated Indian market, US exports of poultry products to India have historically been small, at an estimated \$2 million per year or less. ${ }^{7}$ While Bown and Reynolds (2015) note

7 The exact Harmonized System codes of the products at issue in the dispute are not part of the Panel Report or the Indian government's S.O. 1663(E). Nevertheless, efforts to match 6-digit HS codes with bilateral trade data from UN Comtrade suggest US chicken meat exports to India peaked at roughly $\$ 500,000$ in 2000. Furthermore, in the period around the initiation of the dispute, the largest US export to India on the list was about \$1 million in live birds in 2008 and about \$900,000 in fresh eggs in 2008. 
that this is not unusual, as there are a substantial number of formal WTO disputes over similarly small amounts of realized bilateral trade flows, ${ }^{8}$ the potential that India's expanding middle class might turn from vegetarian-based proteins to chicken suggested a potentially significant growth market for US poultry exporters.

Indian commercial poultry production is quite different from the structure of the US industry (USDA, 2011). Because of minimal availability of cold storage infrastructure, the Indian poultry processing and retail sectors are much smaller than production; as such, poultry commerce is less likely to involve meat and more likely to involve live birds. To the extent that AI is more transmissible via live birds, Indian wariness toward foreign-introduced AI is perhaps more easily understood relative to countries in which commerce is more likely to occur in frozen meat.

Nevertheless, even in the absence of the potential import restrictions related to AI, India maintained an MFN applied import tariff on a number of poultry products that could severely limit trade, ranging from $30.9 \%$ to $111.2 \%$ (USDA, 2011).

\section{The legal claims and issues raised}

Fourteen out of the fifteen claims that the US raised stem from alleged violations of the WTO's Agreement on the Application of Sanitary and Phytosanitary Measures ('SPS Agreement'), ${ }^{9}$ one of the new disciplines added as part of the Uruguay Round. The SPS Agreement was intended to promote the harmonization of SPS standards around international standards developed by the Codex Alimentarius Commission (food safety), the OIE (animal health and safety), and the International Plant Protection Convention (plant health), and to ensure that WTO members' SPS measures are based on sound science and are not more trade restrictive than necessary to protect human, animal, or plant health.

The US challenged India's SPS regime for controlling AI, ${ }^{10}$ which banned imports of ten (mostly poultry and egg) products if they were exported from countries reporting certain types of AI. Because the US had reported incidences of LPNAI outbreaks, its exports were subject to the ban. The challenge included

8 For example, Bown and Reynolds (2015) report that over the period 1995-2011, roughly 14\% of disputes had bilateral trade in the disputed product (before the alleged policy violation) of less than $\$ 1$ million per year.

9 The one non-SPS claim made by the US was that India's AI regime violates Article XI of the GATT, which prohibits the imposition of quantitative restraints or quotas on imports or exports. Because the Panel found that India's measures violated a number of the provisions of the SPS Agreement, the Panel did not find it necessary to rule on the Article XI claim. See Table 2 for a listing of each of the specific claims and Panel rulings in this case.

10 The two principle measures which constituted India's AI regime were the Live-Stock Importation Act of 1898 as amended by the Live-Stock Importation Amendment Act 2001; and S.O. 1663(E), issued by India's Department of Animal Husbandry (Table 1). 
alleged violations of 14 different SPS provisions, with the heart of the US claims centering on:

1. Conformity with international standards: a violation of the SPS Agreement's requirements that India's measure be 'based on' (Article 3.1) or 'conform to' (Article 3.2) international standards, in this case the OIE's Terrestrial Code, Chapter 10.4 .

2. Non-discrimination: a violation of the SPS Agreement's prohibition in Article 2.3 on arbitrary or unjustifiable discrimination, given that India's measure banned domestic trade in poultry products within a $10 \mathrm{~km}$ radius of an AI outbreak in India, while banning imports from the entire US for a breakout anywhere in the country;

3. Scientific basis: a violation of the SPS Agreement's Article 2.2 requirement that measures must be based on scientific principles and sufficient scientific evidence, given the absence of any risk assessment (as required by Article 5.1) performed by India to demonstrate the scientific basis for its measures.

4. Necessity test: India's AI measures, in imposing a ban on all imports of poultry products from the US, are more trade restrictive than necessary to achieve India's desired level of protection (ALOP) against AI.

5. Adaptation to regional condition: India is required under Article 6 to recognize that the US had a system of regions or areas that were certified AI-free and therefore India was not justified in banning imports from the entire country.

6. Transparency: alleged violations of the specific notice and transparency provisions found in Article 7 of the SPS Agreement.

India, for its part, rested very heavily on the SPS Agreement's references to international standards, asserting that its measures 'conform to' the OIE's relevant standards. India insisted that if that were the case, India's compliance with the other provisions of the SPS Agreement must be presumed, and that it was under no further obligation to provide a scientific risk assessment or other proof that its AI measures were based on scientific principles and evidence. For India, conformity with an international standard was the only real obligation imposed on it by the SPS Agreement.

In the end, as can be seen in Table 2, the Panel decided virtually all of the claims in favor of the United States. ${ }^{11}$ However, the way in which the Panel arrived at its decision raises a number of interesting and significant legal issues. First is the significant number of consequential findings made by the Panel, resulting in the building of a 'house of cards', with virtually the entire foundation of the Panel's decisions resting on its first finding that India's measures did not 'conform to'

11 In February 2015, the Government of India filed a notice of appeal contending that the Panel committed errors in its interpretation and application of Articles 2.2, 2.3, 3.1, 3.2, 5.6, 6.1, and 6.2 of the SPS Agreement, along with a number of claims that the Panel failed to make an objective assessment of the matter pursuant to Article 11 of the Dispute Settlement Understanding (DSU). On 4 June 2015, the Appellate Body circulated its report on India's appeal. We do not address questions raised by India's appeal or the $\mathrm{AB}$ decision. 


\section{Table 2. Legal elements of India-Agricultural Products}

Provision Panel finding

SPS 2.2 - (a) only to the extent necessary to protect human, animal, or plant life

(b) based on scientific principles

(c) not maintained without sufficient scientific evidence

SPS 2.3 - no arbitrary or unjustifiable discrimination

SPS 3.1 - measures based on international standards guidelines or recommendations

SPS 3.2 - measures conform to international standards deemed necessary to protect human animal or plant life; if so, presumed to be consistent with the SPS Agreement (India's claim/defense)

SPS 5.1 - measures must be based on a risk assessment

SPS 5.2 - risk assessments shall take into account existence of pest- or disease-free areas

SPS 5.5-no arbitrary or unjustifiable distinctions in the appropriate level of protection

SPS 5.6-measures not more trade restrictive than necessary to achieve their appropriate level of protection

SPS 6.1 - measures adapted to the characteristics of the country or parts of countries from which product originated

SPS 6.2 - required recognition of the concept of pestor disease-free areas and areas of low pest or disease prevalence

SPS 7-notification requirements

Annex B-2-reasonable interval between publication and entry into force

Annex B - 5 (a) - early stage notification

Annex B - 5 (b)-notification to WTO members of products covered

Annex B - 5 (d) - reasonable time for other members to comment

GATT XI - no quantitative restrictions
Violation because more trade restrictive than necessary to protect animal or human life.

Violation of sufficient science requirement because not based on risk assessment.

Violation because (a) India's restrictions apply to a $10 \mathrm{~km}$ radius while imports are banned nationwide, and (b) India has no system to detect LPNAI domestically but banned imports from countries with LPNAI.

Violation: India's measures are not based on the OIE Terrestrial Code because they contradict the OIE Code in parts.

Violation: India's measures do not conform to Chapter 10.4 of the OIE Terrestrial Code because they do not match it exactly.

Violation: India's measures were not based on a risk assessment; no risk assessment undertaken because India presumed its measure conformed to OIE Code.

Violation: India did not undertake a risk assessment and therefore did not take into account any of the 5.2 factors.

Unnecessary to rule, given finding of violation of 2.3.

Violation: India's measures are more trade restrictive than required and are applied beyond the extent necessary to protect human and animal life or health.

Violation: India's measures are not adapted to different SPS conditions in different areas based on finding of no recognition of disease-free areas under 6.2 (cannot ensure adaptation to SPS characteristics of an area without first recognizing the concept of areas).

Violation: India's measures do not recognize the concept of disease-free areas and areas of low disease prevalence because they apply to the entire exporting country.

Violation to all notification requirements because notifications were late or non-existent.

Violation.

Violation.

Violation.

Violation.

Unnecessary to rule, given findings of violation of various SPS provisions. 
the OIE standard. A second important area involved the Panel's engagement with the OIE, including its experts, its written standards and its experts' participation in meetings of the WTO's SPS Committee. Third, the Panel developed new jurisprudence with respect to Article 6's requirement that SPS measures be adapted to the area from which the imports originated and take into account that certain areas (whether entire countries or just part of a country) may be disease-free or have low levels of disease prevalence. ${ }^{12}$

\subsection{It all comes down to the international standards}

The SPS Agreement's Article 3 is at the heart of this case, as it contains the core provisions to promote the harmonization of measures around international standards, guidelines, or recommendations. It starts with the requirement that Members base measures on international standards where they exist (Article 3.1), and follows by giving Members an incentive to do so in that it provides a 'safe harbor' for those measures which 'conform to' international standards (Article 3.2). It then permits Members to deviate from international standards, provided their deviation is to achieve a higher level of sanitary or phytosanitary protection and that there is a scientific justification for that deviation (Article 3.3).

One key premise underlying the Panel's analysis was its reliance on the Appellate Body's EC-Hormones distinction between the interpretive standard applied to Article 3.1, which requires that members base their SPS measures on international standards, guidelines, or recommendations, and Article 3.2, which provides that if a measure conforms to international standards, it is presumed to be consistent with the SPS Agreement. ${ }^{13}$ In EC-Hormones, the Appellate Body set forth (and the India Panel adopted) a very strict definition of Article 3.2's 'conform to' phrase: it requires that an SPS measure 'embody the standard completely' or 'match it exactly'. Article 3.1 , on the other hand, is a less rigorous threshold, permitting a measure to incorporate only some elements of a standard in order to pass the 'based on' test. Therefore, failure to meet the 'based on' threshold in Article 3.1 would also result in a failure to meet the more rigorous 'conform to' threshold in Article 3.2.

\subsection{United States only had to show a discrepancy to prove a violation of Article 3.2}

Once the Panel adopted the definition of the 'match exactly' standard under Article 3.2 , the US could prevail by simply proving the existence of any discrepancy - any

12 There are a number of additional noteworthy issues that are beyond the scope of this paper, including the timing issues raised by the fact that the OIE changes its standards on an annual basis, and the Panel decided to assess whether India's measures were in compliance with the latest standards in effect at the time the Panel was formed, despite the fact that India's measures were adopted before such standards came into existence.

13 Appellate Body Report, European Community - Measures Concerning Meat and Meat Products (Hormones), WT/DS26/AB/R, WT/DS48/AB/R, adopted 13 February 1998, hereinafter EC-Hormones. 
failure to match exactly - between the OIE standard and India's AI regime. Demonstrating a violation of Article 3.2 would then deprive India of its principle defense - its claim that if its measures conform to the OIE standard, then its entire regime is presumed to be based on sufficient science and to be consistent with the SPS Agreement.

The US chose to challenge three discrepancies:

\section{Product coverage}

India's AI regime included two products (live pigs and pathological material and biological products from birds) that were not mentioned or regulated in the OIE's Terrestrial Code. ${ }^{14}$ As such, the Panel found that India could not rely on Articles 3.1 or 3.2 to justify its import ban on those two products. Thus, inclusion of them on India's banned list was a clear failure to 'match exactly' the international standard.

2. NAI versus HPNAI versus LPNAI

The Terrestrial Code set recommendations for specific poultry products in three categories: (1) those from NAI-free countries, zones, or compartments; (2) those from HPNAI-free countries, zones, or compartments; and (3) those regardless of the NAI status of the country, zone, or compartment. India's AI regime, on the other hand, was pitched at NAI with no distinction for high pathogenicity versus low pathogenicity AI. India contended that because the Terrestrial Code provided for three different recommendations, India was entitled to apply one but not necessarily all of them. The question therefore became whether India, in order to demonstrate that its measures 'conformed to' the Terrestrial Code, was required to make a distinction between high pathogenicity and other forms of AI. The Panel answered that question in the affirmative, establishing another discrepancy between India's measures and the OIE standard.

3. Country-wide versus zone or compartment requirements

The US also challenged India's countrywide application of its AI-based import ban, given the Terrestrial Code's recommendations that trade restrictions be applied at the zone or compartment level when appropriate surveillance controls and biosecurity measures are in place to prevent the spread of disease. India argued that it could choose whether to extend its requirements to an entire exporting country or only to its zones or compartments, particularly because the Terrestrial Code consistently referred to the three terms in the alternative: country or zone or compartment. The Panel found that the standard was: if the exporting country does not apply zoning to reduce the size of the affected population, then the measure recommended in the Terrestrial Code should be

14 After reviewing the Terrestrial Code and posing questions to the OIE experts, the Panel determined that there was no relevant international standard for AI that would cover live pigs due to the lack of a scientific connection between pigs and avian influenza. The Panel further determined that there was nothing in Chapter 10.4 (the only applicable international standard) covering pathological materials (i.e., samples from live or dead animals destined for laboratories). 
applied to the entire country. It went on to infer that: if the opposite situation were the case-i.e., if an exporting country does engage in compartmentalization - then an importing country is required to take those zones or compartments into account when developing trade restrictions. Because India's AI regime did not provide for such disparate treatment, its measure was found not to 'conform to' the OIE standards.

\subsection{The house of cards}

The consequences of the Panel's finding that India's measures did not conform to the OIE standard were enormous and led directly to most of the other findings. First, India also violated Article 3.1's requirement that measures be 'based on' international standards, as the same three discrepancies noted above were also evidence that India's measure and the OIE standard contradict each other, with prior Appellate Body rulings noting that measures which contradict an international standard cannot be understood as having been based on that international standard. Second, India violated Article 2.2's requirement that its measures be based on scientific principles. Third, India violated Article 5.1 and 5.2's requirement for a risk assessment, given that India declared that the risk assessment document submitted to the SPS Committee was not an official risk assessment, and its reference to but ultimate refusal to claim that its AI measures were based on Australia's risk assessment meant that India had no risk assessment. Fourth, India violated the non-discrimination provisions of Article 2.3, because the measures treated imports less favourably than domestic poultry by banning imports from anywhere in an exporting country with AI while only banning domestic poultry found within a $10 \mathrm{~km}$ radius of AI outbreak and by banning imports from countries with LPNAI but failing to monitor for LPNAI in India. Fifth, India violated Article 5.6 by imposing measures that were more trade restrictive than necessary, as the Panel found that the very same international standard, the OIE's Terrestrial Code, that India had claimed it was conforming to was instead an alternative measure that India could have reasonably adopted and that would have been less trade restrictive than India's import ban.

Each finding flows directly from the Panel's adoption of the strict 'match exactly' test of what it means to 'conform to' an international standard, with the discrepancies highlighting India's failure to match exactly the OIE standard. Had India's measure been found to conform to the OIE standard, then this entire house of cards would likely have come tumbling down.

\subsection{Engagement with the OIE and the SPS Committee}

The Panel relied heavily on the testimony of experts, on a written exchange with the OIE, and on statements and evidence presented at meetings of the WTO's SPS Committee. Furthermore, the experts and the OIE statements played a central role in the Panel's interpretation of the risk assessment issues, of the interpretation 
of the intent of the OIE standards with respect to import bans, the presence of LPNAI in India, and the conclusion that India was not willing to recognize areas within another country that might be disease-free. As such, this case shines a spotlight on the delicate issues raised by the WTO's deferral of authority to the OIE and of the difficult position faced by the Panel, which was obligated to interpret OIE standards in order to come to its conclusion that India had violated WTO standards. The SPS Agreement leaves the very difficult interpretation of technical standards to the work of a Panel made up of trade experts, while leaving the fate of WTO Members' trade restrictions in the hands of outside technical experts and institutions.

For example, India made one key argument that it was not discriminating against poultry imports from countries that reported LPNAI outbreaks because India did not have LPNAI in its territory. Because LPNAI was 'exotic' to India, the policy was not favoring Indian poultry relative to poultry from countries where LPNAI had been detected. The Panel asked the experts whether India had LPNAI. In a largely backhanded way, the experts answered by noting that LPNAI is virtually ubiquitous in several wild water bird families, particularly ducks, and that India has substantial populations of these wild water birds and ducks. On that basis, the Panel ruled that LPNAI is not 'exotic' to India and therefore India was discriminating by banning imports from countries with LPNAI.

Similarly, there was great controversy over the significance and substance of a document India provided at an SPS Committee meeting entitled 'India's Risk Assessment on Avian Influenza for imposing ban on import of poultry and poultry products from Avian Influenza positive countries (Summary Document)'. India subsequently indicated that the Summary Document was not its final risk assessment, which would take some additional time to prepare. Nearly a year later, the US, apparently unbeknownst to India, sent the Summary Document to the OIE, asking the OIE for its assessment of whether it qualified as a risk assessment. At a subsequent SPS Committee meeting, the US asked that the OIE be given the floor to present its quite critical analysis of India's Summary Document. India, for its part, appears to have taken great umbrage at the presence of the OIE representatives and their criticism of its Summary Document, with India asserting a 'breach of trust reposed by India in the United States' and its view that the OIE acted in disregard of its mandate and overstepped its position as an observer at SPS Committee meetings, since 'the OIE does not have a separate mandate to assess, judge or comment on the existence or content of a Member's risk assessment'.15

15 Panel Report at 7.299. Article 12 of the SPS Agreement calls for substantial engagement between the SPS Committee and the OIE, including permitting requests for examination of 'specific matters with a respect to a particular standard', and OIE participation at a general and educational level in SPS Committee meetings is routine. 


\subsection{New jurisprudence on the required recognition of areas with low-prevalence or no disease}

A third noteworthy development is the Panel's first interpretation of Article 6 of the SPS agreement, which sets forth the requirement that Members ensure that their SPS measures are adapted to the SPS characteristics of the area - whether all of a country, part of a country, or all or parts of several countries. Article 6.2 states that Members shall 'recognize the concepts of pest- or disease-free areas and areas of low pest or disease prevalence', with the determination that such areas be based on factors such as geography, ecosystems, epidemiological surveillance, and the effectiveness of sanitary or phytosanitary controls. The US's basic claim was that India's measures explicitly ban poultry from all parts of the country, thereby ignoring disease-free areas, areas of low disease prevalence, the existence of eradication or control programs, and the relevant OIE guidelines. India countered that the 'recognition of the concept' language does not require any particular form of 'recognition' and that India's form was to accept and evaluate proposals and evidence of pest-free zones, which India claimed the US had never submitted.

The Panel agreed with India that the format of the recognition of the concept of pest- or disease-free areas was not set forth in the SPS Agreement. Nevertheless, it went on to establish the following test: to comply with Article 6.2, 'SPS measures adopted by WTO Members must at a minimum not deny or contradict the recognition of the concepts of such areas when these concepts are relevant with respect to the disease at issue' (Panel Report at 7.698).

The Panel then examined both India's Livestock Act and the regulations imposing the ban on imports from countries reporting NAI (S.O 1663(E)). It found that the Act gives the Indian government wide discretion with no evidence that the discretion has ever been used to recognize, deny, or contradict the recognition of such areas, but it found nothing in S.O. 1663 that allows for the recognition of diseasefree areas within a country that reports NAI. The Panel concluded that S.O. 1663 violates Article 6.2 by imposing a prohibition on a countrywide basis, contradicting the requirement to recognize the concept of disease-free areas.

India contended that it had the legal authority to recognize regions or zones, but that the US never presented a proposal highlighting zones that had been kept free of AI. Here again the Panel relied on SPS Committee statements as evidence in favor of the US's claim that India would not recognize regional zones, as India had stated before the SPS Committee (and to the US Foreign Agricultural Service) that its (country-wide) conditions for imports were 'uniform' for all countries and could not be changed for some and not others. ${ }^{16}$ Within Article 6, the Panel also established another, albeit smaller, house of cards, by first deciding that because India's S.O. 1663 contradicts the requirement to recognize the concept of a 
disease-free area, India had violated the first sentence of 6.2 and that such a violation also automatically resulted in a finding that India violated the first sentence of Article 6.1, which requires Members to ensure that their SPS measures are adapted to the SPS characteristics of the zone. The finding of the violation of the first sentence of Article 6.1 led directly to the violation of its second sentence, which sets out the factors Members must take into account in their adaptation to the SPS conditions of a particular zone. The final 'card' in the house was an additional resultant finding that India violated the second sentence of Article 6.2 by failing to examine the specific, listed factors on which the determination of disease- or pest-free areas or areas of low pest or disease prevalence was to have been based.

\section{Legal-economic analysis and implications of the panel ruling}

This section introduces economic models that incorporate the potential spread of $\mathrm{AI}$ as a negative externality into the commercial market for poultry products, beginning with the simplest model.

\subsection{Some simple economics of avian influenza, standards, and policy intervention}

Assume a partial equilibrium (supply and demand), closed economy model of the poultry market and that AI arises as a negative externality only through poultry production. Poultry production leads to increased incidences of AI, and this disease can spill over beyond the farm and cause other damage to the local economy and society - e.g., to other non-poultry commercial products, into the wild, and potentially to humans.

The first-principles result is that, in the presence of the possibility of AI, if such a poultry market is left 'untreated' by government policy, the market equilibrium will entail too much production and consumption of poultry relative to the social optimum, as poultry producers do not internalize the entire social costs of their production. The resulting economic inefficiency identifies a welfare-enhancing role for government intervention and national regulation.

The well-known first-best policy response is for the government to impose a Pigouvian tax on poultry production equivalent to the size of the negative externality, i.e., the damage the AI causes to the rest of the economy. Relative to no policy intervention, the imposition of such a tax incentivizes producers to face the full (private plus externality) social costs of their production. The standard result holds that some amount of AI (the externality) is nonetheless likely to arise in equilibrium; i.e., complete eradication of AI may be too costly relative to its social benefit.

While this simple description focuses on Pigouvian taxes, in reality, the optimal government policy intervention to address the AI externality is more complicated and nuanced. For example, in lieu of a tax, the government may implement 
inspection procedures and mandatory stamping out regimes designed to identify and contain AI outbreaks. More sophisticated regulatory regimes may seek to address the problem of asymmetric information - i.e., that farmers, firms, and potentially even governments could have a disincentive to reveal private information that they learn about local AI outbreaks.

While such policies are clearly relevant for the real world, for ease of exposition, our formal economic analysis will remain limited to a discussion of an optimal tax policy. In broad terms this tax should be interpreted as merely an indicator for a directed government policy intervention. Despite this admittedly simplistic approach, the framework is sufficiently rich to identify important implications of the impact of international trade and international institutions such as the OIE.

\subsection{The OIE, global public goods, and standard-setting in the face of externalities}

A collection of member governments and other interested parties, including foundations (e.g., Gates Foundation) and other inter-governmental organizations (e.g., the WTO and FAO), fund the OIE. Our baseline assessment is that the institutional design features of the OIE are broadly consistent with insights arising from a basic economic model. Three specific examples include its provision of public goods, its assistance to the global community in overcoming free-rider problems, and, in the case of AI, that its standards differentiate between HPNAI and LPNAI.

The OIE provides to the world trading system important public goods, such as knowledge and information that is non-rival and non-excludable. It contributes knowledge about animal disease by regularly convening scientific panels of experts and establishing standards for conditions under which certain diseases are sufficiently problematic as to require policy intervention. Second, it collects and disseminates information about disease outbreaks to the world.

The OIE also helps countries overcome what would otherwise likely result in a number of free rider problems. First, the globally optimal underlying level of scientific research on diseases like AI is less likely to arise without OIE coordination due to under-investment at the national level-i.e., scientific knowledge discovered by one country could not be kept from spilling over to other countries. ${ }^{17}$ Second, the OIE serves as a centralized clearing house of information to assist monitoring and information dissemination about disease outbreaks. A world without the OIE would likely result in an additional free rider problem in which bilateral or regional surveillance initiatives would arise that provided a more geographically limited (sub-global) public good.

The OIE differentiates its standards for goods produced in countries infected with HPNAI, for which it advocates relatively severe and costly policy

17 A related likely benefit is that the OIE's set of 'global' standards is less costly for global traders to meet than if they had to tailor their products for different standards in each individual market. 
interventions, versus for goods produced in countries that have 'only' been infected with LPNAI, for which the OIE advocates less costly policy interventions limited to surveillance. This is qualitatively consistent with the basic Pigouvian argument introduced above that high levels of regulation should target the high damage externality (HPNAI) and low levels of regulation should attack the low damage externality (LPNAI).

\subsection{Linking international standards organizations and trade agreements}

Here we examine the trade policy and WTO issues involved by sequentially introducing additional complexities to the model analyzed above.

\subsubsection{Baseline analysis - small countries and local bird flu externalities}

Consider a static (one shot) model with two producing countries-country U (which also exports) and country I (which also imports) - that are assumed to be 'small' enough that their trade does not affect foreign prices. Continue to assume the AI externality is strictly local.

Introducing trade into the model leads to the standard result that each country gains relative to autarky; nevertheless, there will be winners and losers within each country. The importing country's consumers gain through lower prices and additional quantities of consumption, and import-competing domestic producers of poultry lose. In the exporting country, producers of poultry gain and domestic consumers lose through higher prices and lower quantities consumed at home. ${ }^{18}$ On the other hand, if country I imposed a new import restriction, the identities of these winners and losers would simply be reversed.

With small countries and a negative local production externality, the policy implications noted above continue to hold: the first best policy outcome involves governments in both countries allowing free trade in poultry products, but each government should be permitted the domestic policy flexibility to attack AI with a domestic production tax equal to the size of the local externality. Any alternative policy that does not address the externality at its source would be inefficient in that it would introduce what is known as a by-product distortion (Bhagwati and Ramaswami, 1963).

At this point, there is no efficiency-enhancing role for an interventionist trade policy - such as tariffs or, as we further elucidate below, import bans - in this setting. In the absence of a trans-boundary component to the AI externality, if first best policies like domestic taxes and inspections are available, there is no

18 In a general equilibrium model that considers factors of production, other standard distributional results on winners and losers would obtain, some of which may be used to explain pressure on the government in I for import restrictions for protectionist purposes. For example, in the short run, factors tied to the production of poultry (that cannot shift to other expanding sectors) in the importing country would lose, and in the long-run, factors intensively used in the production of poultry would lose. 
efficiency motive for introducing a trade policy to address the externality. ${ }^{19}$ This particular result is consistent with at least one aspect of the OIE's general standards and its treatment of LPNAI. Because there is no trans-boundary externality associated with products produced in countries with LPNAI outbreaks, there is no role for restrictive trade policy to target imports from those countries.

\subsubsection{Small countries and trans-boundary bird flu externalities}

Next we consider a critical modification to our assumptions by supposing that some forms of AI have externalities that are also trans-boundary. Here the key distinction is between outbreaks of high-damage HPNAI versus low-damage LPNAI. To clarify for modeling purposes, it is not the production of the poultry in the exporting country $U$ that gives rise to an additional (non-local) externality in country I. Instead, we assume the poultry produced in country U must be traded from $\mathrm{U}$ to $\mathrm{I}$ for the additional, trans-boundary externality to arise in country $\mathrm{I}^{20}$

In a series of papers, Costello and McAusland (2003), McAusland and Costello (2004), and McAusland (2008) consider implications on optimal policymaking of these types of trans-boundary externalities in the presence of international trade. ${ }^{21}$ McAusland and Costello (2004) allow for countries to address such trans-boundary externalities with two policy instruments - an import tariff and port inspections. They find that the optimal import tariff is positive and set at its Pigouvian level, which in this case is the sum of the port inspection costs and the anticipated economic damage associated with those imported goods not rejected at the port. ${ }^{22}$

The intuition for optimal government policymaking follows the same targeting principle (Bhagwati and Ramaswami, 1963) - attack the externality at its source. In this case, because the trans-boundary component of the externality arises only through trade, the optimal targeted intervention to address that component of the externality would be a Pigouvian tax on only the trade. This leads to a different first-best policy outcome relative to Section 4.3.1, in which the AI externality was purely 'local'. With both local and trans-boundary externality components, the optimal policy outcome would also involve two components: (1) each country of

19 A related result is found in the more general and large country model of Bagwell and Staiger (2001). See also Staiger (2015).

20 While this framework does fit the scenario of this particular dispute between geographically separated India and the US, we recognize that in cases of geographical proximity the trans-boundary externality could also arise through production. For example, the US outbreak of HPNAI in 2014 in Washington State may have resulted from a prior HPNAI outbreak across the border in Canada (OIE, 2014).

21 This series of research papers was not motivated by bird flu but by the introduction of "exotic species' from country I into country U via the conduit of international trade; e.g., a particular insect, pest, or weed being transported alongside a commodity aboard a container ship and causing economic damage to country's I's domestically produced crops and wildlife.

22 If the country chooses not to inspect imported goods but allows all to enter, then the first part of the Pigouvian tariff (associated with the costs of inspection) is zero, and the Pigouvian tariff is equal to the expected costs of the damage to the domestic economy associated with total imports of poultry. 
production ( $\mathrm{I}$ and $\mathrm{U}$ ) imposes a Pigouvian production tax that is equivalent to the size of the local production externality, and (2) the country of import (I) imposes a separate and additional Pigouvian import tax that is equivalent to the size of the trans-boundary component of the externality.

We interpret the OIE's basic framework for treating trade in poultry and other potentially AI-impacted products as establishing a system for governments to follow this logic for policymaking. In specific instances in which there is a sufficiently high probability of trans-boundary transmission of a costly externality e.g., in countries of production where HPNAI has been detected - the OIE allows for heightened regulations such as additional trade restrictions and increases in inspections. On the other hand, in instances where there is no trans-boundary externality-e.g., because there is no scientific evidence of possibly economically harmful transmission of AI in countries with 'only' LPNAI outbreaks - the OIE standards do not justify a government policy intervention that would impede trade flows.

When viewed through this framework, the economic argument against India's complete import ban on poultry from a country where any form of AI is present whether HPNAI or LPNAI - is that such a policy is too costly. The import ban on LPNAI goods raises the price to Indian consumers above the socially optimal level, it decreases consumption below the socially optimal level, and it also increases domestic production of poultry above the socially optimal level. ${ }^{23}$

One additional question is raised by the results of McAusland and Costello (2004) regarding the implications for optimal policy design when country I has multiple trading partners that differ in the characteristics of their trans-boundary externalities, such as their infection rates, the expected damages (externality costs) to I associated with such infections, as well as differences in their production costs. These considerations may be particularly relevant in light of general WTO/ GATT requirements for non-discrimination, particularly MFN treatment. If countries are constrained legally with respect to their tariffs, the model indicates that it may be optimal for them to compensate by discriminating in their application of other complementary policies, such as the rigor with which they conduct inspections of trading partners based on their AI-infection rates. Indeed, the intuition behind the issue of discrimination for trans-boundary externalities would also apply if the AI can be contained within regions of the same country (e.g., US poultry produced in Georgia versus Iowa). The policy implication would be a

23 Furthermore, Costello and McAusland (2003) also show the possibility that even trade barriers that target externality costs (from introduction of exotic species in their model, trans-boundary AI in our model) can lower overall economic welfare in country I. In this case, while import barriers targeting imports from AI-infected countries may lead to less ecological damage in India associated with foreign-introduced AI, the reduction in India's imports could result in an increase in domestic poultry production which has its own associated costs, including increased local negative externalities associated with India's own AI and the economic costs of being the less efficient provider (globally) of poultry. 
less-than-country-wide ban even in the presence of HPNAI; if regions in a country can be split into HPNAI-affected and HPNAI-unaffected regions, the optimal policy would distinguish between the two. This is roughly consistent with the Terrestrial Code's principle of 'zoning' or 'regionalization'.

\subsubsection{Large countries and bird flu externalities}

Finally, the analysis is likely to change if countries are 'large' and can shift some of the costs of their policy choices onto trading partners through a reduction in foreign exporter-received prices for their poultry. ${ }^{24}$ While we are not aware of a specific model in the literature that has focused on our exact scenario-i.e., local production externalities and additional, trans-boundary externalities - we found relevant a model with negative consumption externalities where the consumption good can be produced locally or imported (Staiger and Sykes, 2011). The Staiger-Sykes approach is motivated by disputes such as EC-Hormones and EC-Asbestos, where Panels were asked to consider standards that were alleged to be too high (relative to the social optimum), and whether there were economic incentives for such standards to arise in practice when countries are involved in trade agreements such as the WTO. ${ }^{25}$

Staiger and Sykes (2011) show that after a trade agreement constrains the country's import tariff through tariff bindings, if the importing country is further constrained by a national treatment requirement to impose the same, nondiscriminatory standard on the domestically produced and imported good, the government will have an incentive to 'over-regulate'. The government raises its standard to a level that is higher than optimal because it is 'large' and can shift some of the costs of those higher standards onto the trading partner through the reduction in foreign exporter-received prices. Staiger and Sykes conclude that in such a scenario, in order to achieve the first best outcome, the agreement also requires a rule to prevent excessively stringent regulation and domestic taxes; without such a rule, governments have a unilateral incentive to make such policies excessive so as to shift some of the costs onto trading partners through reductions in exporters' received prices (terms of trade).

To the extent that such a result were to also arise in a model with trans-boundary externalities, this might identify another potential role for the OIE - it could help to establish the maximum levels of acceptable standards to prevent such international cost-shifting from taking place. Furthermore, the 'exceptions' to the OIE framework may also be consistent with such an interpretation - countries like I can be permitted to impose higher-than-OIE standards, but in order to do so, they must

24 Bagwell et al. (forthcoming) provide a survey of these and other related models of trade agreements arising in the economics literature. See also Ederington and Ruta (forthcoming).

25 EC - Hormones; Panel Report, European Communities - Measures Affecting Asbestos and Asbestos-Containing Products, WT/DS135/R and Add.1, adopted 5 April 2001, as modified by Appellate Body Report WT/DS135/AB/R. 
bear the cost of conducting additional risk assessments and providing scientific evidence that such regulations are warranted.

\section{Conclusion: public policy implications}

While our legal-economic analysis is broadly supportive of the India-Agricultural Products Panel Report, the institutional design of the OIE, and elements of its Terrestrial Code that establish and apply 'standards' for Avian Influenza, we conclude by highlighting four important public policy issues. ${ }^{26}$

First, the OIE's standard setting role is one that balances long-run and short-run tradeoffs between transparency and policy flexibility. We interpret the rather sharp line that the OIE draws between permissible interventions toward products from HPNAI-affected versus LPNAI-affected countries-and, in particular, OIE's rather forceful reaction against India's position in the dispute - as stemming from the OIE's concern that permitting import restrictions in the case of LPNAI could result in even less transparency regarding AI outbreaks over the long run. Under a strict interpretation of current OIE standards for LPNAI, countries have no disincentive to report LPNAI outbreaks because such outbreaks cannot trigger import restrictions by trading partners in the absence of additional scientific evidence generated through costly independent risk assessments. Put differently, if the OIE allowed a country to 'get away' with imposing import restrictions after outbreaks of only LPNAI, trading partners would be discouraged from reporting LPNAI outbreaks in the first place, leading to more uncertainty and furthering the severity of already existing information asymmetries. This could change the nature of the 'repeated' game between countries and make cooperation over trade and regulatory agreements less likely to be sustainable. ${ }^{27}$

Indeed, evidence from the Panel Report suggests an already substantial asymmetry in the reporting of LPNAI across countries. Whether due to technical capacity, resource constraints, or something else, the testimony from the three experts brought in by the Panel indicated that India did not have a comprehensive surveillance regime in effect that would systematically allow it to detect LPNAI. From this asymmetric information starting point, the OIE would surely prefer the outcome whereby informational 'symmetry' across countries is restored through a process by which India increased its monitoring and domestic surveillance relative to an outcome whereby the US and other countries (that are currently monitoring and reporting) decreased their surveillance activities.

26 India-Agricultural Products, WT/DS430/R.

27 Repeated game models with externalities typically contain either local externalities only (e.g., Ederington, 2001) or trans-boundary externalities that arise through production and not necessarily trade (e.g., Limão, 2005). These models build from the basic repeated game models of prisoner's dilemmas introduced by Bagwell and Staiger (1990). Other models exploring the information dissemination role of trade agreements include Maggi (1999) and Park (2011). 
A second potential concern is how this dispute threatens, over the longer-term, the OIE's role in the trading system. On the one hand, the deference that the WTO Panel showed to the OIE legitimizes it as a provider of global public goods and an independent scientific expert on sound levels of standards. The efficiencyenhancing properties of the OIE described in Section 4.2 also help put into perspective any potential political 'costs' to national governments associated with loss of sovereignty due to forced harmonization of standards and policy.

The public policy concern is that the WTO put the OIE in the middle of a politically sensitive commercial dispute between its members that may have unintentionally weakened the source of the OIE's strength that derives from its political independence and ability to base its standards and policy advice on sound scientific evidence. Similar political pressure has already confronted other standards-setting international organizations such as Codex Alimentarius in light of the ECHormones and EC-Approval and Marketing of Biotech Products disputes. ${ }^{28}$

A third concern is the long-run impact of this dispute on the SPS Committee. India was certainly put off by the fact that materials that it had shared informally with other WTO members in the SPS committee were brought into formal litigation. Will this make countries less likely to utilize the SPS committee to share, discuss, and potentially resolve their differences without having to turn things over to a Panel?

Fourth, is it feasible for countries to employ less-than-country-wide SPS measures to deal with HPNAI and other similar disease outbreaks? Recent events suggest that such regulatory cooperation across countries can be achieved, even after the occurrence of HPNAI outbreaks. Specifically in 2014-2015, after the issuance of the Panel Report, the US experienced a number of HPNAI outbreaks that began in wild birds and eventually were found in commercial poultry establishments. US farmers had to 'stamp out' upwards of 50 million chickens and turkeys, and the US Department of Agriculture notified the public and the global community through the OIE.

While a number of trading partners announced immediate bans on all US poultry exports, regardless of whether the source was in a location deemed as 'HPNAI-free' by US veterinary scientists after testing (USDA, 2015b), the European Union treatment of US exported poultry provides an important exception to this response and potential guidance for how countries can implement in practice the regulatory cooperation envisaged by the OIE. ${ }^{29}$ In late March 2015, the European Commission

28 For a discussion of Codex Alimentarius in particular, see Pollack and Shaffer (2009). See also Foster (2011) for a discussion of Codex, OIE, and the use of scientific experts in related WTO disputes. ECHormones; Panel Report, European Communities - Measures Affecting the Approval and Marketing of Biotech Products, WT/DS291/R, Add.1 to Add.9 and Corr.1/WT/DS292/R, Add.1 to Add.9 and Corr.1/WT/DS293/R, Add.1 to Add.9 and Corr.1, adopted 21 November 2006.

29 Coincidentally, the European Union had a similar WTO dispute involving 'regionalization' ongoing at the time against Russia over live pigs and pork products due to African Swine Fever (Russian Federation - Measures on the Importation of Live Pigs, Pork and Other Pig Products from the European Union, WT/ DS475). 
(2015) announced Implementing Regulation 2015/526, in which it did not implement an import ban on US poultry products; instead, the regulation can be interpreted as following the OIE 'regionalization' guidelines that distinguish between zones within an exporting country regarding HPNAI-free status.

\section{References}

Bagwell, Kyle, Chad P. Bown, and Robert W. Staiger (forthcoming), 'Is the WTO Passé?' Journal of Economic Literature.

— and Robert W. Staiger (1990), 'A Theory of Managed Trade', American Economic Review, 80(4): 779-95.

- (2001), 'Domestic Policies, National Sovereignty, and International Economic Institutions', Quarterly Journal of Economics, 116(2): 519-562

Bhagwati, Jagdish and V. K. Ramaswami (1963), 'Domestic Distortions, Tariffs, and the Theory of Optimum Subsidy', Journal of Political Economy, 71(1): 44-50.

Bown, Chad P. (2015), Temporary Trade Barriers Database, The World Bank, June, http://econ.world bank.org/ttbd/.

and Kara M. Reynolds (2015), 'Trade Flows and Trade Disputes', Review of International Organizations, 10(2): 145-177.

— and Joel P. Trachtman (2009), 'Brazil-Measures Affecting Imports of Retreaded Tyres: A Balancing Act', World Trade Review, 8(1): 85-135.

Costello, Christopher and Carol McAusland (2003), 'Protectionism, Trade, and Measures of Damage from Exotic Species Introductions', American Journal of Agricultural Economics, 85(4): 964-975.

Ederington, Josh (2001), 'International Coordination of Trade and Domestic Policies', American Economic Review, 91(5): 1580-1593.

— and Michele Ruta (forthcoming), 'Non-Tariff Border and Behind-the-Border Measures', in Kyle Bagwell and Robert W. Staiger (eds.), The Handbook of Commercial Policy, Elsevier.

European Commission (2015), 'Commission Implementing Regulation (EU), 2015/526 of 27 March 2015 amending Annex I to Regulation (EC) No. 798/2008 as regards the entry for the United States in the list of third countries, territories, zones or compartments from which certain poultry commodities may be imported into or transit through the Union in relation to further outbreaks of highly pathogenic avian influenza in that country', Official Journal of the European Communities.

FAO (2014), 'Empres Watch: Avian Influenza A(H5N6): The Latest Addition to Emerging Zoonotic Avian Influenza Threats in East and Southeast Asia', Food and Agriculture Organization of the United Nations, Volume 30, November, 1-6.

Foster, Caroline E. (2011), Science and the Precautionary Principle in International Courts and Tribunals: Expert Evidence, Burden of Proof and Finality, Cambridge: Cambridge University Press.

Hoekman, Bernard and Joel P. Trachtman (2010), 'Continued Suspense: EC-Hormones and WTO Disciplines on Discrimination and Domestic Regulation Appellate Body Reports: Canada/United States-Continued Suspension of Obligations in the EC-Hormones Dispute, WT/DS320/AB/R, WT/DS321/AB/R, adopted 14 November 2008', World Trade Review, 9(1): 151-180.

Horn, Henrik and Joseph H. H. Weiler (2003), 'European Communities-Measures Affecting Asbestos and Asbestos-Containing Products', in Henrik Horn and Petros C. Mavroidis (eds.), The WTO Case Law of 2001, Cambridge: Cambridge University Press, pp. 14-41.

Howse, Robert L. and Henrik Horn (2009), 'European Communities - Measures Affecting the Approval and Marketing of Biotech Products', World Trade Review, 8(1): 49-83.

Limão, Nuno (2005), 'Trade Policy, Cross-border Externalities and Lobbies: Do Linked Agreements Enforce More Cooperative Outcomes?', Journal of International Economics, 67(1): 175-199.

Maggi, Giovanni (1999), 'The Role of Multilateral Institutions in International Trade Cooperation', American Economic Review, 89(1): 190-214. 
McAusland, Carol (2008), 'Trade, Politics, and the Environment: Tailpipe vs. Smokestack', Journal of Environmental Economics and Management, 55(1): 52-71.

— and Christopher Costello (2004), 'Avoiding Invasives: Trade-Related Policies for Controlling Unintentional Exotic Species Introductions', Journal of Environmental Economics and Management, 48(2): 954-977.

Neven, Damien J. and Joseph H. H. Weiler (2006), 'Japan-Measures Affecting the Importation of Apples (AB-2003-4): One Bad Apple?', in Henrik Horn and Petros C. Mavroidis (eds.), The WTO Case Law of 2003: The American Law Institute Reporters' Studies, Cambridge: Cambridge University Press, pp. 280-310.

OIE (2014), 'Immediate Notification Report: United States of America', Reference REF OIE 16759, 16 December.

Park, Jee-Hyeong (2011), 'Enforcing International Trade Agreements with Imperfect Private Monitoring', Review of Economic Studies, 78(3): 1102-1134.

Pollack, Mark A. and Gregory C. Shaffer (2009), When Cooperation Fails: The International Law and Politics of Genetically Modified Foods, Oxford: Oxford University Press.

Staiger, Robert W. (2015), 'Non-Tariff Measures and the WTO', Mimeo, Dartmouth College, July.

— and Alan O. Sykes (2011), 'International Trade, National Treatment, and Domestic Regulation', Journal of Legal Studies, 40(1): 149-203.

USDA (2011), 'India: Poultry and Products', Foreign Agricultural Service, Global Agriculture Information Network Report, 30 November, US Department of Agriculture.

_ (2015a), 'Poultry and Eggs: Statistics and Information', Economic Research Service, US Department of Agriculture, http://www.ers.usda.gov/topics/animal-products/poultry-eggs/statistics-information. aspx (accessed 23 April 2015).

(2015b), 'Export Library - Requirements by Country', US Department of Agriculture Food Safety and Inspection Service, http://www.fsis.usda.gov/wps/portal/fsis/topics/international-affairs/export ing-products/export-library-requirements-by-country (accessed 2 May 2015). 